namjera ponuditi vlastiti jedinstveni

\section{Rob Stones}

\section{Why Current Affairs Needs Social Theory}

London: Bloomsbury Academic, 2015, 224 str.

Rob Stones jedan je od brojnih socioloških autora čiji je teorijski projekt krajem 20. stoljeća pao u sjenu tzv. relacijske sociologije koja je ujedinila mnoge posebne grane sociologije naglaskom na zajedničkim »neprijateljima« u vidu teorije racionalnog izbora, »modernističkog« holizma, mjerenja varijabli i preguste etnografije. Alternativa koju relacijska sociologija nudi sastoji se od napuštanja svake tradicionalne aksiomatike u korist praćenja ishoda raznovrsnih i sveprisutnih društvenih relacija. Stonesovo rano programatsko djelo Sociological Reasoning: Towards a Past-Modern Sociology iz 1996. zagovara sličnu teorijsku i istraživačku gipkost kao i relacijska sociologija, tako da mu njezino promicanje $\mathrm{u}$ teorijsku ortodoksiju nije osujetilo, nego omogućilo uglavnom neometanu daljnju razradu vlastitih ideja. Štoviše, upravo je svojevrsna konsolidacija sociološke perspektive implicitna pretpostavka najnovije Stonesove knjige Why Current Affairs Needs Social Theory. Istina, Stones naglašava pluralizam društvenih teorija, ali osnovna mu je model tumačenja društva koji baštini sve ono što smatra dobrim u sociološkoj tradiciji. Autor je uvjeren da bi se takav model mogao pokazati posebno korisnim pri procijeni kvalitete medijskih sadržaja.

Stones najavljeni model razrađuje kroz pet poglavlja i zaključak knjige koja je predmetom ovog prikaza. U prvome, $»$ What we should look for in television news« (str. 1-25), on predstavlja za komunikacijske znanosti standardnu raščlambu »operacija medijskih okvira« (definicija problema, dijagnoza uzroka, moralni sud i prijedlog rješenja) kao okosnicu svog pristupa. Naime, autor pokazuje kako bi se korisnici medijskih sadržaja uvijek trebali pitati je li ih neki izvještaj informirao o tome što se dogodilo, zbog čega, kako se prema tome postaviti i koje su daljnje mogućnosti djelovanja. U narednom poglavlju, »Contextual fields and social theory« (str. 27-58), Stones nudi svoje viđenje najkorisnijih socioloških konceptualnih alata za analizu dometa medijskih izvještaja. Zatim u poglavlju »What we do when we make sense of Borgen« (str. 59-93) pokazuje da dobar dio tih alata široka publika već intuitivno primjenjuje. Završna poglavlja »Making the most of what we already know: Interpreting single reports on unfamiliar issues« (str. 95-123) i »Interpreting the bigger picture« (str. 125-165) upozoravaju na manjkavosti 
pojedinačnih izvještaja i širih narativnih analiza te upućuju na korištenje višestrukih izvora kako bi se zadovoljili u ranijim poglavljima knjige prikazani i razrađeni kriteriji. Zaključak knjige je svojevrsni apel da ovakvu vrstu objektivnosti naširoko počnu primjenjivati $\mathrm{i}$ novinari i publika.

Stonesa zapravo muči raskorak između sofisticiranosti obrada umjetničkih i znanstvenih sadržaja u medijskoj sferi naspram onih društvenih i političkih. Dakako, istu vrstu nelagode često izražavaju progresivniji autori, političari pa i sami konzumenti vijesti, ali posebnost je Stonesova prigovora u tvrdnji da upravo društvena teorija može ponuditi lijek za taj raskorak te u njegovu nastojanju da takav lijek i ponudi. Naime, on smatra da bi medijski radnici i njihova publika literarnu imaginaciju (kakvu već ionako posjeduju) trebali potkrijepiti rigoroznošću i dubinom uvida koje nudi društvena teorija. U suprotnom se publiku izlaže nekontekstualiziranim i neempatičnim izvještajima, a onda posljedično zbunjenosti i fatalizmu. Kao prvi korak predlaže postavljanje pitanja kako izvještaj definira problem, njegove uzroke, potencijalna rješenja i prostor za moralni sud. Iako tu raščlambu posuđuje od komunikacijskih znanosti, Stones smatra da i samoj toj disciplini nedostaje društvene teorije kako ne bi samo opisivala što mediji čine, nego i počela valorizirati upravo kako to čine.

Koje to analitičke alate društvena teorija nudi za spas medija, njihovih korisnika, pa i cijele znanstvene dis- cipline, od banalnosti izvještavanja? Središnji analitički pojam Stonesove sociologije jest kontekstualno polje, sa svojim objektivnim i subjektivnim polom. Tako bi svaki izvještaj trebao što jasnije predstaviti objektivne faktore relevantnoga kontekstualnog polja: aktere, kronotopski kontekst, ciljeve, resurse, međuovisnosti, kulturu i ograničenja. Također, morao bi pokušati dočarati subjektivne faktore koji ograničuju djelovanje bitnih aktera: poznavanje polja, poznavanje drugih aktera, habitus, neposredni strahovi, osjećaj prostora za manevar, hijerarhija prioriteta. Ako je neki dio prikaza manjkav, teorijski informirana publika morala bi to moći prepoznati i tražiti druge izvještaje kako bi dobila što potpuniju sliku.

Stonesova posebna vrlina jest njegova senzibiliziranost za umjetnost što pokazuje ne samo upornim stavljanjem naglaska na hermeneutičku dimenziju društvene teorije, nego i ustupcima u smjeru shvaćanja popularne kulture kao njezinoga potencijalnog saveznika. Poglavljem koje je posvećeno danskoj televizijskoj seriji Borgen razmatra se zavidna razina kompetencije gledatelja koje suvremene televizijske serije pretpostavljaju. Kako bi razumjeli epizodu Borgena, gledatelji moraju primijeniti mnoge uvide sociološkog promišljanja, od razumijevanja objektivnoga kontekstualnog polja do empatije sa subjektivnim horizontom protagonistice. Autor knjige time otvara važan prostor za suradnju društvene teorije i širih kritičkih refleksija o umjetnosti, 
a stvara i potencijal za »regrutaciju« obožavatelja popularnih sadržaja među sociološki kompetentne korisnike medijskih izvještaja.

Ipak, mora se primijetiti da Stonesova varijanta sociološkog promišljanja pati od nekih poznatih mana relacijske perspektive. Prije svega pati od nespremnosti pridavanja ikakvih »supstantivnih« odlika društvenim fenomenima. Fleksibilnost svođenja društvenog svijeta na polja i mreže relacijska sociologija plaća izvjesnom suhoćom uvida, odnosno izostankom velikih »modernističkih» narativa. Vrline supstantivnih određenja inače eklektični Stones koristi samo dok prokazuje površnost shvaćanja demokracije u izvještajima koji su puč na Tajlandu 2006. predstavili kao oglušivanje bivše monarhije na volju naroda. Tako misli da bi novinari, da su uzeli u obzir i ostale dimenzije demokracije (vladavina prava, ljudska prava i civilno društvo) a ne samo volju većine, drukčije procjenjivali svrgnuti režim. Ostatak se knjige ipak fokusira na relacijskoj sociologiji podobnije pitanje »što se dogodilo?«, odnosno manjkavosti izvještavanja već na planu opisa uzroka, a ne na njihovoj površnosti kod daljnjeg pitanja »kako se prema tome postaviti?«. Primjerice, kad Stones opisuje potpunu zbunjenost novinara suočenih s problemom loših usluga u javnim (zdravstvenim) ustanovama prisiljenim na »racionalno« poslovanje, on ukazuje na to da novinari pristaju uz supstantivnu matricu neoliberalnog odnosa prema javnom dobru, iz koje je nemoguće misliti niz konkretnih sustavnih problema pa se izvještaji svode na prazne moralne osude zaposlenika zdravstvenog sustava. Iako se dijagnostičke i normativne razine analize međusobno prožimaju, Stonesova je matrica opremljena prije svega za pobijanje interno nekonzistentnih izvještaja, a ne za izbor između različitih tumačenja problema.

Problem nesklonosti supstantivnim formulacijama tako se dalje proteže i na problem nejasnoga normativnog okvira Stonesove knjige. Naime, autor opetovano upozorava na opasnost dekontekstualiziranog moraliziranja, ali ne nudi okvire za postavljanje moralnog suda nakon što se kontekst upozna. Čini se da se razumijevanjem konteksta i uvažavanjem drugih aktera nužno donose prave političke odluke. Prilikom takve argumentacije susprezanje od velikih ideja i narativa dovodi do pomalo banalnih odgovora na stvarne političke izazove, što Stonesa ipak ne priječi da se obruši na praznu »objektivnost« mnogih medijskih izvještaja i inzistira na izvrgavanju argumenata različitih vrijednosnih orijentacija istim kriterijima održivosti. U suvremenom kontekstu dominacije nerijetko apsurdnih lažnih ekvivalencija, nekritičnoga pukog davanja jednakoga medijskog prostora sukobljenim stranama, možda je moguće tu vrstu formalizma uzeti za strastveni prosvjetiteljski idealizam.

Vodeći svoju analizu kraju, autor priznaje da je njegov apel vjerojatno ograničenog dometa kad su u pitanju novinari. Korporativni i politički pritisci bitno određuju koliko istančano novi- 
nari smiju predstavljati probleme. Ipak, DOI: $10.5613 /$ rzs.46.3.6 alternativni bi mediji trebali obratiti pozornost na njegove ideje. Jedan od rijetkih pozitivnih efekata smanjivanja povjerenja u državne institucije jest poprilično otvoreno i živo područje borbe tumačenja društvene stvarnosti, gdje se, između zastarjelih srednjostrujaških formula i zabavnih teorija zavjere, alternativni mediji imaju priliku stalno iznova dokazivati najsuvislijima. Iako im je prioritet borba za vlastitu strukturnu održivost, presudno je da održivost postignu inzistiranjem na kvaliteti svojih tumačenja, u čemu im je Stones partner kako autorskim entuzijazmom, tako i analitičkim uvidima.

Osim medijskih radnika, drugi profil publike za Why Current Affairs Needs Social Theory jesu oni pripadnici akademske zajednice (mahom sociolozi) koji vjeruju da je društvena teorija najbolji rezervoar tumačenja društvenog svijeta. Dapače, relacijska sociologija u tome je izdašna polazišna točka i lako ju je dalje nadopunjavati pojedinačnim ingenioznim doprinosima iz njezinih više od sto godina tradicije. Stonesov je projekt blizak svima koji to obilje žele približiti ostatku svijeta.

Leonard Jurić Zagreb

\section{Proslava 40. godišnjice Odjela za sociologiju Sveučilišta u Zadru}

Zadar, 20. travnja 2016.

Odjel za sociologiju Sveučilišta u Zadru 20. travnja 2016. godine obilježio je 40. godišnjicu svojega znanstvenog i nastavnog djelovanja svečanom proslavom i prigodnom akademskom raspravom. Toj značajnoj obljetnici prisustvovali su brojni uzvanici i gosti koji s Odjelom surađuju u okvirima svojega akademskog i stručnog djelovanja. Iz programa proslave i izlaganja bilo je primjetno da su se razvojni fokus $i$ primarno usmjerenje Odjela mijenjali tijekom godina u skladu s aktualnim društvenim promjenama kao i potrebama struke da se istraživački i kritički osvrne na njih.

Govori uzvanika, uzvanica i domaćina proveli su nazočne kroz zaokruženu priču djelovanja Odjela za sociologiju od vremena osnivanja 1976. godine, kao Odsjeka pri tadašnjem Filozofskom fakultetu u Zadru, pa sve do danas. Svojim su prisjećanjima na rad i suradnju s nekima od brojnih sociologa i sociologinja poput Ivice Maštruka, Nikole Skledara, Đure Šušnjića, Mislava Kukoča, Darka Polšeka, Erme Ivoš Nikšić, Anči Leburić i Inge Tomić-Koludrović, koji su se tijekom tih četrdeset godina, između ostaloga i u okvirima Odjela, profilirali unutar hrvatske sociologije, predočili prisutnima ustrajnost u izgradnji kvalitetnih 